\title{
Perspectives Social Sufism in Remediation Crisis Moral in Humans Modern
}

\author{
N Ishmah ${ }^{1}$, H Aliyah ${ }^{2}$ \\ ${ }^{1}$ Islamic Building School of Jagad Alimussirry Surabaya, Indonesia \\ ${ }^{2}$ Science Department, Universitas Negeri Surabaya \\ Email: nihayatulishmah11@gmail.com
}

\begin{abstract}
Urgency science of Sufism is to foster moral self- humans both in the affairs of the world and the affairs of the Hereafter later. The problem is related to morals or behavior possessed by humans. Modern society will tend to hold opinions and behave freely because all humans have the same rights and do not distinguish degrees or power. Such freedom can affect changes in human behavior which can also lead to deviant behavior in terms of religion. This freedom encourages society to be individualistic, materialistic and hedonism. The implementation of Sufism can be applied as a moral guidance for modern society to keep on doing world worship with the worship of the hereafter as well. Balance in life will happen well.
\end{abstract}

Keywords: Science Sufism; Modern Society; Moral Coaching

\section{INTRODUCTION}

Sufism has a connection with the heart in themselves human. This is evident from the purpose of the existence of Sufism. Science Sufism aims to improve heart and focus it only with Allah alone. Objectives are related to the urgency of the science of Sufism. Urgency science of Sufism itself is fostering moral self- humans both in the affairs of the world and the affairs of the Hereafter later.

The use of Sufism continues to be used until modern times. The modern era can be marked by advances in science and technology. Although the development of the times that the more modern, a problem that is faced by people not diminished but tended to increase so that the science of Sufism allegedly very help cure the disease in the community. Problems are associated with moral or behavior behavior that is possessed by humans.
The phenomenon of moral at times modern can be felt not only by the age of adulthood, but also the age of adolescence. Moral who owned more decreased due to increasingly free man to access a variety of information that relates well to the culture alien that can lower the morale in humans. In addition to a case that, humans will increasingly have an understanding and knowledge are different. Society modern would tend to argue and behave freely because all human beings have the right to the same and does not distinguish between degrees and power. Such freedom can affect changes in human behavior which can also lead to deviant behavior in terms of religion.

Freedom that encourages people to be individualistic, materialistic and hedonistic [1]. These characteristics are the properties that are accepted in the religion of Islam. The phenomenon is that becomes contradictory behind the development of the times with the laws in Islam. 
Implementation science of Sufism in life everyday can help reduce the crisis of morality that. Due to the essentially the science of Sufism also build morale within ourselves human. In addition to that, humans can balance the development of the modern with the remains into a man whose religious, creative and always have innovation in solving the problems that exist in the era of modern like this.

\section{METHOD}

This study uses a summary of the literature to be able to reveal how Sufism in the problematic relationship between education and life. The literature used including books, articles, and websites trustworthy. By comparing the various exposures of the literature, the authors analyze, implement and to find role of Sufism in remidiating moral crisis of modern society.

\section{RESULT AND DISCUSSION}

\section{A. Social Sufism}

The definition of the meaning of Sufism is divided into two meanings, namely in terms of language and terms. In language, Sufism comes from the words Ahlussuffah, shafiyyun, and shuf [3]. Ahlussuffah means the people who moved with the Prophet from Mecca to Medina. Shafiyyun means holy. Whereas shuf means rough wool fabric made from fur.

Whereas in terms, many scholars interpret the meaning of Sufism. SH Nasr stated that Sufism is essentially the deepest and esoteric dimension of Islam (the inner and esoteric dimension of Islam) which originates from the Qur'an and al-Hadith. Hamka called it "modern Sufism", namely "out of despicable character and enter into commendable character". The intention is to cleanse the soul, educate and enhance the degree of mind, stress all trials and greed, combat excessive lust from the need for selfcenteredness [5].
Then this "moral" Sufism from the beginning, in several main aspects, even arranged to bind the Qur'anic doctrine. In fact, to call it "morals" is an abuse of the term. Morals master intra-human relationships and the morals of the Qur'an do this with a strong sense of presence of God [5].

The reappearance of Sufism in modern times is a form of re-actualization of Islamic teachings. It also can streamline the function of religion as a "source of meaning and guidance for life". The implementation of Sufism can be seen from social Sufism that emphasizes the moral development of humans in this modern era.

The concept of social Sufism according to Amin Syukur is Sufism that does not separate between the nature and shari'ah (fiqh) and also remains involved in life and worldly life, does not separate between the world and the hereafter [4].

A person who practices Sufism means training himself with sincerity (riyadhah mujahadah) to cleanse, enhance, and deepen the spiritual aspects in order to draw closer to Allah SWT. so that all attention is only on Him. Whereas the purpose of adding the word "social" in this case is to make people who practice Sufism also have to be active in social life, because it is the responsibility of Sufidi in the current era to have a positive impact on social life.

\section{B. Social Crisis in Modern Times}

The moral crisis that struck the Indonesian nation was as a result of a spiritual crisis. Because the diversity of the Indonesian people in general, especially Muslims, is more concerned with religion in its formal form rather than a sense of inner appreciation of religion, so that religion does not cause any impression on their souls. The impact is also influenced by modernization. 
Modernization is characterized by the use of technology and the development of science in various aspects of life [1]. These developments create a change in attitude from human beings as well. Modern life as well as materialistic life, individualistic and selfish attitudes, competition in life, and lifestyle of hedonism.

Materialistic means love for wealth and excessive power. Individualistic attitude is an attitude that is selfish without thinking of others around it, so that what arises is always the existence of unfair competition. Finally there is hedonism which means a lifestyle that attaches temporary worldly pleasures to the exclusion of the afterlife.

Meanwhile, according to Amin Syukur, Muslims today live in the modern era. The era in which the life of the community is completely rationalist, secularist, materialist, and the like. Such attitudes turned out to be a problem in its own community. The things that are considered to be able to provide life happiness, apparently it is not able to provide life satisfaction, even cause anxiety in life.

\section{The Role of Sufism in the Moral Crisis}

Social Sufism connects the harmony between world life and the afterlife. World life is used as an intermediary or a means to draw closer to God and towards a good afterlife. Understanding the world in the perspective of Sufism is identified with wealth and position. A good world life can be seen from how the substance, how to get it and how to use it. If both go well, then the balance of life and life goals will be achieved.

Sufism makes a positive contribution that can be practiced in Indonesia. In modern society it can be used as a solution for the community, as the spiritual fortress in the modern face is problematic [2]. To overcome the problems of modern society, Sufism must be the most important alternative.
According to Amin Syukur, a Sufi (person who practices Sufism) today must be more able to be in society, not live alone anymore [4]. For example zuhud, zuhud which means a simple life, whether in clothes, eating, drinking, and others, must be adapted to the context of the era. The presence or absence of matter is the same, remaining stable in life. Although it does not rule out psychologically swaying with matter, because as a creature it has two dimensions, namely spiritual and physical. Both must be fulfilled in order to be used as a means of worshiping Allah SWT. So, in other words, zuhud does not mean exclusively from worldly life, because it is forbidden by Islam, Islam advocates a spirit of struggle, a spirit of sacrifice, and work, not being lazy.

Sufism is right in the view of Amin Syukur, is Sufism that balances between physical and spiritual aspects. Both aspects are very important, both are symbiotic, they need each other. If the system or spiritual aspect is sick, then the system or physical aspect will get sick too. That is what Abdul Muhayya calls a spiritual crisis, where a spiritual crisis for humans causes various mental illnesses that can cause various harms both for oneself and for others. In addition, the spiritual crisis will also reduce human dignity to the brink of destruction that threatens civilization and human existence.

\section{CONCLUSION}

Based on the description in the above, and be concluded that: Sufism not only teaches to draw closer to God in a way that is stagnant. But with the times, Sufism can be applied in ways that are appropriate to the times. In addition, the urgency of Sufism is very influential for changes in this modern era. Tasawuf appplied can help people to overcome the problem so that a proper balance between the life of the world's life and in the hereafter. 


\section{REFERENCES}

[1] Achlami, H. (2015). Tasawuf Sosial Dan Solusi Krisis Moral. Ijtimaiyya, 8(1), 90-102.

[2] Aliyah, H. (2018). Sufistic Education , A Urgency Of Age Modernity, 1 (November), 1013.

[3] Fahrudin. (2016). Tasawuf sebagai upaya bembersihkan hati guna mencapai kedekatan dengan Allah. Jurnal Pendidikan Agama Islam Ta'lim, 14(1), 65-83.

[4] Gunawan, A. (2017). Konsep tasawuf sosial prof. dr. h. m. amin syukur, m.a., dan relevansinya dengan tujuan pendidikan islam.

[5] Mannan, A. (2018). Esensi Tasawuf Akhlaki Di Era Modernisasi. Aqidah-Ta: Jurnal Ilmu Aqidah, $4(1)$. https://doi.org/10.24252/aqidahta.v4i1.5172 